\title{
AGRONOMIC PERFORMANCE OF CONTENDER AND AMARELO JAPONÊS CULTIVARS UNDER DIFFERENT WATER REPLACEMENTS ${ }^{1}$
}

\author{
JANAINA BORGES DE AZEVEDO FRANÇA ${ }^{2 *}$, FREDERICO ANTONIO LOUREIRO SOARES ${ }^{3}$, NEI PEIXOTO², \\ MUZA DO CARMO VIEIRA ${ }^{4}$, ANDERSON DIAS VAZ DE SOUZA ${ }^{2}$
}

\begin{abstract}
The use of cultivars appropriate to the soil and climate characteristics of a region provides farmers with security by facilitating credit for crop financing and improving product prices in local commerce. The objective of this work was to evaluate the agronomic performance of "Contender" and "Amarelo Japonês" green bean bush cultivars grown in the Cerrado in terms of water replenishment (RH) of 25, 50, 75, 100, and $125 \%$ of evaporation using the Piché evaporimeter. The experiment was carried out in the experimental area of the State University of Goiás, on the Ipameri Campus. The experimental design was a randomized block design. Sowing was done in May 2017, with treatments distributed in a split-plots scheme with water replenishment in plots and cultivar subplots with 3 replications. The analyzed variables were: height; stem diameter; leaf number; leaf area; number of inflorescences; number of flowers; fresh and dry mass of the plant; number, length, diameter, fresh and dry mass of the pods. The different water replenishment rates increased the mean plant height, stem diameter, number of pods per plant, number of bean seeds per pod, and number of bean seeds per plant in the cultivars "Amarelo Japonês" and "Contender." Water replenishment of 125\% produced higher development and better agronomic performance in the two cultivars than the other rates.
\end{abstract}

Keywords: Cultivation. Cerrado. Influence of irrigation. Green bean.

\section{DESEMPENHO AGRONOMICO DAS CULTIVARES CONTENDER E AMARELO JAPONES SOB DIFERENTES REPOSIÇÕES HÍDRICAS}

\begin{abstract}
RESUMO - O uso de cultivares apropriadas às características edafoclimáticas de uma região, proporciona segurança aos agricultores, facilitando a obtenção de crédito para o financiamento do cultivo e melhorando a cotação do produto no comércio local. Este trabalho teve como objetivo avaliar o desempenho agronômico, das cultivares arbustivas de feijão-vagem "Contender" e "Amarelo Japonês” em reposição hídrica (RH) de 25; 50; $75 ; 100$ e $125 \%$ da evaporação do evaporímetro de Piché cultivadas no Cerrado. O experimento foi instalado na área experimental da Universidade Estadual de Goiás Câmpus Ipameri. O delineamento experimental utilizado foi de blocos casualizados. Foi realizada a semeadura em maio de 2017, com tratamentos distribuídos em esquema de parcelas subdivididas, tendo nas parcelas as reposições hídricas e nas subparcelas as cultivares, com 3 repetições. As variáveis analisadas foram: altura; diâmetro do caule; número de folha; área foliar; número de inflorescências; número de flores; massa fresca e seca da planta; número, comprimento, diâmetro, massa fresca e seca das vagens. Houve incremento nas médias de altura de planta, diâmetro de caule, número de vagens por planta, número de grãos por vagem, número de grãos por planta nas cultivares "Amarelo Japonês" e "Contender", à medida em que se incrementaram as reposições hídricas. A reposição hídrica de $125 \%$ desenvolvimento foi superior às demais quanto desempenho agronômico das duas cultivares.
\end{abstract}

Palavras-Chave: Cultivo. Cerrado. Influência da irrigação. Feijão-vagem.

\footnotetext{
${ }^{*}$ Corresponding author

${ }^{1}$ Received for publication in 12/05/2017; accepted in 10/08/2019.

Paper extracted from the doctoral thesis of the first author.

${ }^{2}$ Campus Ipameri, Universidade Estadual de Goiás, Ipameri, GO, Brazil; janainaborgesdeazevedofranca@gmail.com - ORCID: 0000-00031814-0274, nei.peixoto48@gmail.com - ORCID:0000-0003-2319-8139, andersondias_99@hotmail.com - ORCID:000-0001-6229-3417.

${ }^{3}$ Campus Rio Verde, Instituto Federal Goiano, Rio Verde, GO, Brazil, fredalsoares@hotmail.com - ORCID: 0000-0002-4152-5087.

${ }^{4}$ Department of Biotecnology, Campus Urutaí, Instituto Federal Goiano, Urutaí, GO, Brazil; mcvmuza@gmail.com - ORCID: 0000-00031730-9541.
} 


\section{INTRODUCTION}

Green bean, Phaseolus vulgaris, also known as snap bean, is an annual herbaceous plant with a superficial root system. It belongs to the Fabaceae family and presents good adaptation in climates with temperatures ranging between 18 and $30^{\circ} \mathrm{C}$ (FILGUEIRA, 2013; PEIXOTO; CARDOSO, 2016).

According to the aforementioned authors, the pods, the product of this crop, are harvested when immature and tender, with poorly developed bean seeds; and the ideal harvesting point is when the pods reach full development, but before becoming fibrous and seedy. In practice this point is identified as when the tips or the pedicel are easily broken.

The yield of undetermined growth cultivars of green beans ranges from 10 to $16 \mathrm{t} \mathrm{ha}^{-1}$, but under special cultivation conditions it can reach over $20.5 \mathrm{t}$ $\mathrm{ha}^{-1}$ (FILGUEIRA, 2003; 2008; PEIXOTO; CARDOSO, 2016).

Water management in irrigated crops, according to Fernandes (2010), is a function of factors related to crop, climate, and soil, which will determine the amount of water to be applied and the timing of irrigation.

According to Carvalho et al. (2006), irrigation and fertigation, in the phase of cultivation, significantly influence the crown diameter, plant height, and number of total plagiotropic branches.

Allied to problems related to water availability, the implementation of an efficient management program, the National Water Resources Policy established in Law 9.433 / 1997, contributed to the incorporation of water management and optimization of the efficient use of water resources as well as consumption (MANTOVANI; BERNARDO; PALARETTI, 2009).

Plant performance is a factor that contributes to detecting genetic variability within populations of the same species, and the relationships between this variability and environmental factors. This information supports the characterization of environmental and their establishment and survival (MATHEUS; LOPES, 2007).

Studies on the effects of efficient management of irrigation on the agronomic performance of some species have been performed (PEIXOTO et al., 2002; MENDONÇA; RASSINI, 2006; MOREIRA et al., 2009; OLIVEIRA, 2013; SILVESTRE et al., 2016; ZHANG et al., 2016; HALAGALIMATH; RAJKUMARA, 2018). However, there are no studies for all planting regions for the most consumed cultivars. Thus, it is relevant to make this information available for each region.

In this context, it is important from a regional point of view to evaluate the agronomic performance of bean plants and pods, and to make available to the small producer, information for the cultivation of different cultivars under different water replacements, establishing cultivation and management options.

The objective of this work was to evaluate the agronomic performance of "Contender" and "Amarelo Japonês" green bean cultivars grown in the Cerrado in terms of water replacement (WR) of $25,50,75,100$, and $125 \%$ of evaporation using a Piché evaporimeter.

\section{MATERIAL AND METHODS}

The experiment was carried out at Goiás State University, on the Ipameri Campus (geographic coordinates of $17^{\circ} 71^{\prime} 82$ " south latitude and $48^{\circ} 14^{\prime}$ 35 " west longitude), from May to July 2017. The altitude in the area is $800 \mathrm{~m}$. The region's climate, according to the Köppen classification (PEEL, FINLAYSON, MCMAHON et al., 2007) is defined as Tropical Humid (AW), with high temperatures, summer rains, and winter drought. The soil of the experimental area is classified as Dystrophic RedYellow Latosol (EMBRAPA, 2006).

The experimental design used was randomized blocks with treatments distributed in a split plot of $5 \times 2$, with 3 replications. The plots consisted of irrigation levels determined by water replacement $(\mathrm{RH})$ corresponding to $25,50,75,100$, and $125 \%$ of evaporation using a Piché evaporimeter, and the subplots evaluated the cultivars "Contender" and "Amarelo Japonês."

The soil was conventionally prepared by plowing once and harrowing twice. At 60 days before sowing, $779 \mathrm{~kg} \mathrm{ha}^{-1}$ of dolomitic limestone with relative power of total neutralization of $92 \%$ was applied to increase the base saturation of the layer from $0-20 \mathrm{~cm}$ to $60 \%$. At sowing $20 \mathrm{~kg} \mathrm{ha}^{-1}$ of $\mathrm{N} ; 100 \mathrm{~kg} \mathrm{ha}^{-1}$ of P205; and $60 \mathrm{~kg} \mathrm{ha}^{-1}$ of $\mathrm{K}_{2} \mathrm{O}$, formulated 5-25-15, were applied. Additionally, 140 $\mathrm{kg} \mathrm{ha}{ }^{-1}$ of urea (according to previous studies unpublished data) was applied as a source of nitrogen 20 days after germination.

The experiment consisted of five rows of five meters of plants, in which the two outer rows formed the borders. The central row was used to evaluate the production variables and the other two intermediate rows were used to evaluate agronomic characteristics and conduct destructive analyses.

The management of the crop in relation to the incidence of weeds was done by hand weeding at imminent risk of competition.

A drip type irrigation system was used, with a dripper hose with a spacing of $0.20 \mathrm{~m}$ emitters and a flow rate of $2.4 \mathrm{~L} \mathrm{~h}^{-1}$. The need for irrigation application was recommended from the Piché Evaporimeter (MENDONÇA; RASSINI, 2006) and crop coefficient (kc) (OLIVEIRA, 2013).

Plant Height $(\mathrm{PH})$ : obtained by quantifying the height of the plants, corresponding to the 
distance from the neck to the end of the main stem and with the help of a ruler and expressed in $\mathrm{cm}$.

Stem diameter (SD): obtained by measuring the cross section of the stem, using a digital caliper, sampling ten pods per plot, expressed in $\mathrm{mm}$.

Number of leaves per plant (NL): obtained by counting the leaves in sampling of 10 plants per plot, expressed in units.

Leaf Area (LA): Total Leaf Area: Length was measured along the central rib, considering the distance from the leaf apex to the insertion of the limb with the petiole, and the largest width perpendicular to the rib alignment, using a ruler. These measurements were used to estimate the leaf area following the formula suggested by Figueiredo, Santos and Garcia (2012).

The variables analyzed were:

$\mathrm{LA}=\Sigma(0.575$. $(\mathrm{LxW}))$,

where: LA is the leaf area $\left(\mathrm{cm}^{2}\right)$; L is the leaf length $(\mathrm{cm}) ; \mathrm{W}$ is the width of the leaf $(\mathrm{cm})$.

Number of inflorescences (NI): obtained by averaging ten sampled inflorescences per plot.

Plant fresh mass (PFM): obtained by quantifying the weight of ten whole pod plants in each plot, expressed in grams.

Plant dry mass (PDM): obtained by quantifying the weight of fresh plants, oven dried, expressed in grams.

Pod number $(\mathrm{PN})$ : expressed by counting the total number of pods produced in ten plants per plot.

Pod length (PL): was obtained by quantifying the longitudinal length of the pods, with the aid of a graduated ruler, sampling ten pods per plot, expressed in $\mathrm{cm}$.
Pod diameter (PD): obtained by measuring the cross section of the pod with the aid of a digital caliper, sampling 10 pods per plot, expressed in $\mathrm{mm}$.

Pod fresh mass (FMP): obtained by quantifying the weight of the pods in each plot, expressed in grams.

Pod dry mass (DMP): Obtained by quantifying the weight of the dried green beans, in grams.

Data for each variable were subjected to analysis of variance by the F test using the Sisvar program (FERREIRA, 2011). When significant, a polynomial regression analysis was performed, and the model with the largest significant fit was adopted.

\section{RESULTS AND DISCUSSION}

Table 1 shows that there were significant differences between the averages of the plants, at the level of 5 and $1 \%$ probability by the $\mathrm{F}$ test, for all characteristics, when the water replacement was evaluated separately for the studied cultivars. Regarding the evaluation of significance between cultivars, it was found that it was observed for the number of PH, NI and PDM .

The interaction between the cultivars and water replenishment was significant for plant height, leaf area, and plant dry mass revealing the performance of these characteristics in the cultivars "Amarelo Japonês" and "Contender" with the different water replacements in the research plot (Table 1 and Figures 1A, 1B, 1C).

Table 1. Summary of variance analysis for plant agronomic characteristics of "Amarelo Japonês" and "Contender" green bean cultivars as to: plant height; stem diameter; number of leaves per plant; leaf area; number of inflorescences; number of flowers; plant dry mass and plant fresh mass, irrigated with water replacements.

\begin{tabular}{|c|c|c|c|c|c|c|c|c|c|}
\hline \multirow{2}{*}{ VS } & \multirow[b]{2}{*}{ DF } & \multicolumn{8}{|c|}{ Values of $F$} \\
\hline & & $\begin{array}{c}\mathrm{PH} \\
(\mathrm{cm})\end{array}$ & $\mathrm{SD}(\mathrm{mm})$ & $\begin{array}{l}\text { NL } \\
\text { (un) }\end{array}$ & $\mathrm{LA}\left(\mathrm{mm}^{2}\right)$ & NI (un) & $\begin{array}{l}\mathrm{NF} \\
\text { (un) }\end{array}$ & $\operatorname{PDM}(\mathrm{g})$ & PFM (g) \\
\hline Block & 2 & $281^{\mathrm{NS}}$ & $1.33^{\mathrm{NS}}$ & $3.16^{\mathrm{NS}}$ & $0.02^{\mathrm{NS}}$ & $1.36^{\mathrm{NS}}$ & $0.21^{\mathrm{NS}}$ & $1.23^{\mathrm{NS}}$ & $2.99^{\mathrm{NS}}$ \\
\hline $\mathrm{C}$ & 1 & $29.26^{* *}$ & $2.70^{\mathrm{NS}}$ & $1.07^{\mathrm{NS}}$ & $1.97^{\mathrm{NS}}$ & $9.78 * *$ & $0.06^{\mathrm{NS}}$ & $7.15^{*}$ & 3. $14^{\mathrm{NS}}$ \\
\hline WR & 4 & $24.18^{* *}$ & $7.01 * *$ & $21.02 * *$ & $31.51^{* *}$ & $6.18^{* *}$ & $5.66 * *$ & $13.09 * *$ & $23.01 * *$ \\
\hline CxWR & 4 & $5.26^{* *}$ & $0.77^{\mathrm{NS}}$ & $0.88^{\mathrm{NS}}$ & $6.98 * *$ & $0.15^{\mathrm{NS}}$ & $1.20^{\mathrm{NS}}$ & $1.25^{\mathrm{NS}}$ & $2.98^{*}$ \\
\hline $\mathrm{CV} \%$ & --- & 12.05 & 14.31 & 16.32 & 29.86 & 57.63 & 59.61 & 31.73 & 20.74 \\
\hline
\end{tabular}

VS variation source; DF degree of freedom; PH plant height; SD stem diameter; NL number of leaves; LA leaf area; NI inflorescence number; NF number of flowers; PDM plant dry mass and PFM plant fresh mass; C Cultivar; WR Water Replacements $(25,50,75,100$, and $125 \%)$. ${ }^{* *}$ Significant at $1 \%$ probability; * Significant at 5\% probability; NS not significant. CV Coefficient of variation. 
The different manifestations of cultivars can be explained by the competition of plants for environmental factors such as temperature, light intensity, length of day, soil, water availability, as well as the genetic characteristics of the studied materials (TAIZ et al., 2017). These conditions can influence the stem diameter, number of leaves, leaf area, and consequently flower production. Thus, under higher plant densities in the plant row, there is less availability of photosynthesis products for vegetative growth, with photoassimilates destined for plant growth in height (PEIXOTO et al., 2002).

In Figures $1 \mathrm{~A}, 1 \mathrm{~B}$, and $1 \mathrm{C}$, it is verified that an increase occurred as a function of unit increment for each variable analyzed. For plant height this increment was $0.50 \%$; leaf area $3.68 \%$, and dry mass of $75.24 \%$ when RH was between $25 \%$ and $125 \%$.
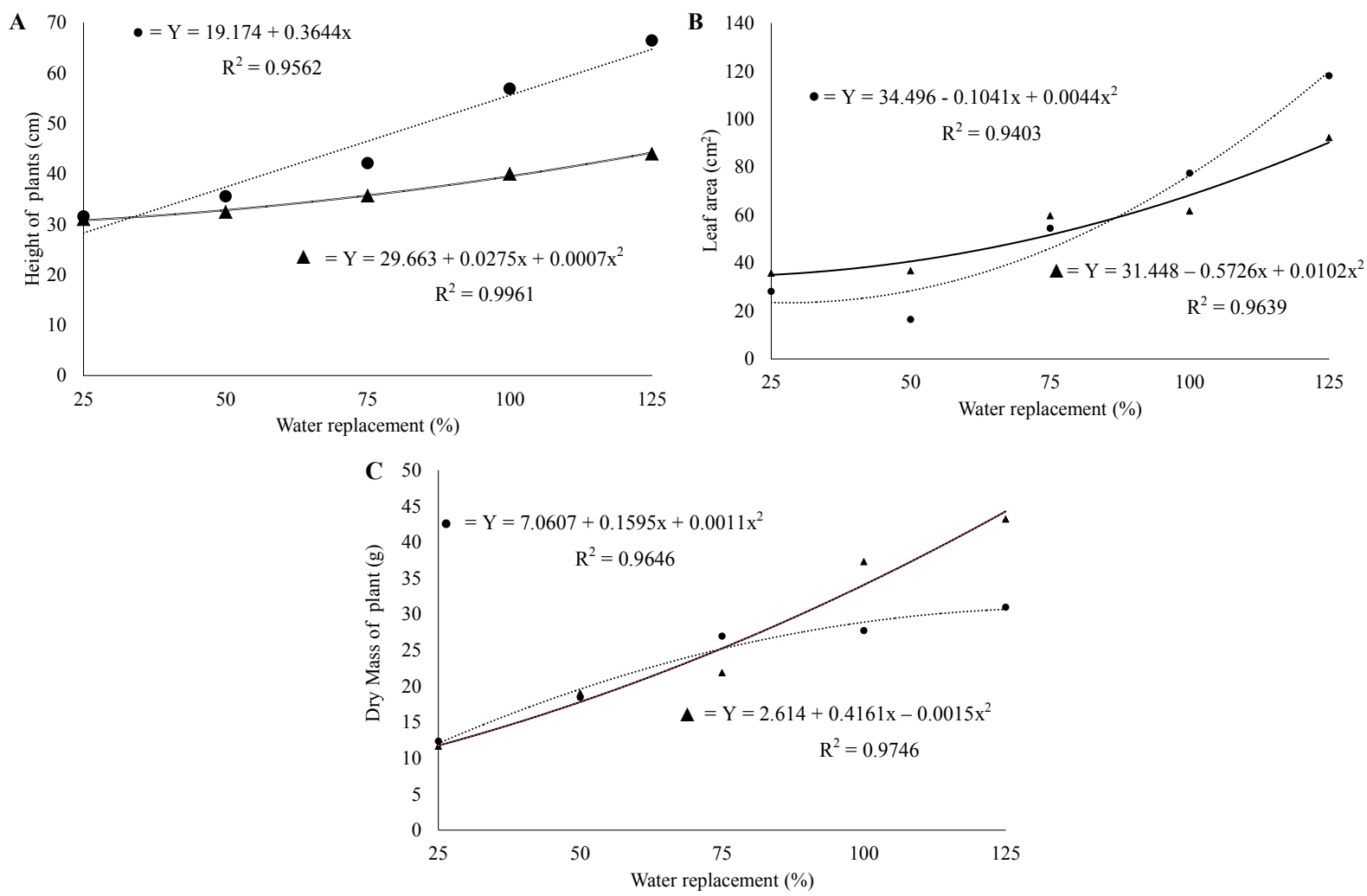

Figure 1. Agronomic characteristics of green beans ("Amarelo Japonês" and "Contender") regarding: Interaction between WR and cultivars: A) plant height $(\mathrm{cm})$; B) leaf area $(\mathrm{cm})$; C) dry mass $(\mathrm{g})$; irrigated with different water replacements $(25,50,75,100$, and $125 \%)$.

In Figures 2A, 2B, 2C, 2D, 2E, and 2F, for each variable analyzed, there was an increment as a function of WRs in which the average values for stem diameter (Figure 2A) ranged from 7.89 to 7.77 $(\mathrm{mm})$ for WR $125 \%$ for the cultivars "Amarelo Japonês" and "Contender" respectively. When observing the percentage increase between 25\% and $125 \%$ WR in the cultivars "Amarelo Japonês" and "Contender," the percentage differences in the values were $24.46 \%$ and $34.36 \%$.

Regarding the number of leaves, the value for the cultivar "Amarelo Japonês" was also higher for WR of $125 \%$ compared to the cultivar "Contender" under the same conditions, for reasons that may be related to genotype and its interaction with the environment. The environment can exert an important influence on plant performance as argued by Zhang et al. (2016) in studies with soybean on photosynthetic performance of soybean plants in water deficit under high and low light intensity. The authors worked with two irrigation regimes $(75+/-$ $2 \%$ of field capacity) and two light intensity treatments. They point out that shaded soybean plants were influenced by drought conditions in which there was an increase in chlorophyll, chlorophyll b, carotenoid, carbon-chlorophyll ratio, relative leaf water content, leaf area per plant, intercellular $\mathrm{CO}^{2}$ concentration, perspiration rate, and electron transport rate. In this sense, this approach to survey the performance of pod beans under Cerrado conditions may give evidence of the behavior of these cultivars, offering assistance to small local producers that still lack this information. 

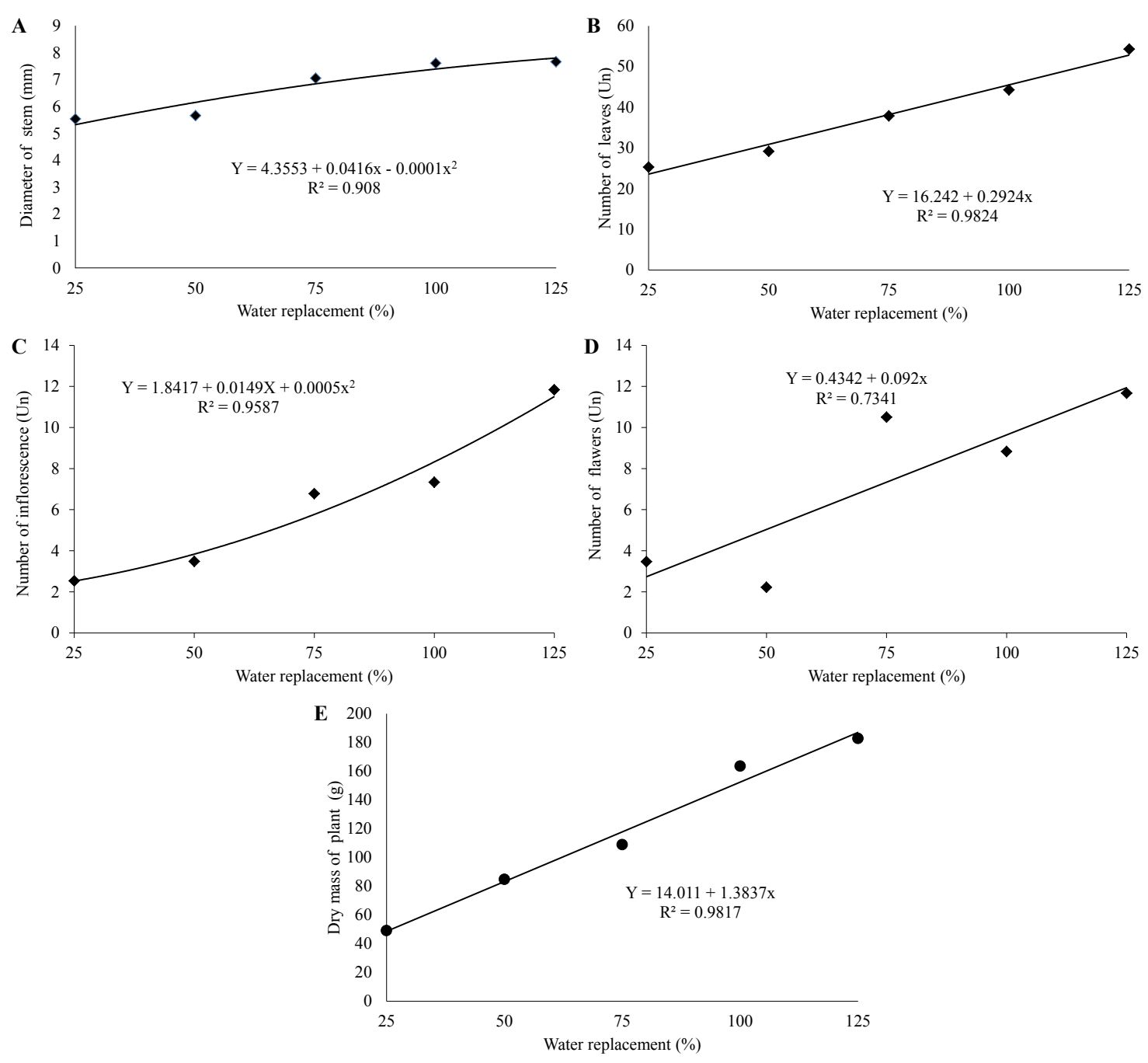

Figure 2. Agronomic characteristics of green beans ("Amarelo Japonês" and "Contender") regarding: A) stem diameter (mm); B) number of leaves (un); C) number of inflorescences (un); D) number of flowers; E) Dry mass (g); irrigated with different water replacements $(25,50,75,100$, and 125\%).

In the data found in Table 2 regarding the agronomic performance characteristics, we observed interaction between WR and cultivar only for the dry mass of the pod (PDM). In the other variables, the interaction between the factors studied was not evidenced.

The number of inflorescences presented higher average values for the cultivar "Amarelo Japonês" with WR of $125 \%$ as well as higher number of flowers by inflorescence with values of 13.0 (inflorescence) and 12.0 (flowers). The inflorescence phenomenon is an important factor in the evaluation of yield and productivity of an agricultural crop (TAIZ et al., 2017). Studies on water deficiency in cultivated plants can provide information that contributes to the selection of regional cultivars. Manifestations of these materials with respect to different WRs may make available to the small producer plant materials that best fit the needs of each locality. Thus, these indices give evidence that these cultivars have viable attributes for cultivation in the Cerrado.

Regarding the analysis of the fresh and dry mass of plants observed in the equations, the mean values were more expressive for "Amarelo Japonês." However, it should be noted that "Contender" also presented interesting values for production at the evaluated site. It is important to address the various characteristics of the cultivars under study for each specific region, as each of them may, due to environmental factors and genetic factors, present a differentiated type of phenotypic expression either in terms of development and / or when evaluating crop production.

As for the water deficit tolerance in the different WR's (Figures 3A, 3B, 3C, 3D, and 3E), 
there was a quadratic effect for all analyzed variables. It also presents positive correlations for the variables analyzed regarding their cultivation under the conditions in which the study was conducted. From this perspective, studies aimed at irrigation management contribute to the knowledge about the management of different crops, as observed in studies on morphological and physiological responses of acai seedlings submitted to different water regimes (SILVESTRE et al., 2016). These authors studied seedlings submitted to water regimes corresponding to $40,70,100$, and $130 \%$ of field capacity. Irrespective of plant material, vigorous seedling production was feasible only under water regimes of $100 \%$ and $130 \%$ of field capacity. Of these, seedlings produced under $130 \%$ of field capacity showed higher height, stem diameter, leaf number, total leaf area, root and leaf biomass, total biomass, and shoot root ratio. In the study carried out with green beans (Table 2), it is possible to observe that in relation to WRs there was significant difference for all analyzed variables including number of pods, pod length, pod diameter, fresh pod mass, and dried pod mass.

Table 2. Summary of analysis of variance for agronomic characteristics: number of pods, pod length, pod diameter, pod fresh weight and dry mass of cultivars (C) "Amarelo Japonês" and "Contender" bean cultivars irrigated with different water replacements (WR) percentage.

\begin{tabular}{lcccccc}
\hline \multirow{2}{*}{$\begin{array}{l}\text { Source of } \\
\text { variation }\end{array}$} & $\begin{array}{l}\text { Degree of } \\
\text { Freedom }\end{array}$ & PN $(\mathrm{un})$ & $\mathrm{PL}(\mathrm{cm})$ & $\mathrm{PD}(\mathrm{mm})$ & $\mathrm{FMP}(\mathrm{g})$ & $\mathrm{DMP}(\mathrm{g})$ \\
\cline { 3 - 7 } & 2 & $5.71^{*}$ & $0.23^{\mathrm{NS}}$ & $1.43^{\mathrm{NS}}$ & $2.36^{\mathrm{NS}}$ & $1.25^{\mathrm{NS}}$ \\
$\mathrm{Block}$ & 1 & $0.41^{\mathrm{NS}}$ & $2.11^{\mathrm{NS}}$ & $8.90^{* *}$ & $3.18^{\mathrm{NS}}$ & $0.62^{\mathrm{NS}}$ \\
$\mathrm{C}$ & 4 & $19.23^{* *}$ & $18.03^{* *}$ & $4.43^{*}$ & $19.74^{* *}$ & $19.21^{* *}$ \\
$\mathrm{WR}$ & 4 & $0.89^{\mathrm{NS}}$ & $0.69^{\mathrm{NS}}$ & $0.20^{\mathrm{NS}}$ & $0.27^{\mathrm{NS}}$ & $6.28^{* *}$ \\
$\mathrm{C} \mathrm{x} \mathrm{WR}$ & --- & 26.52 & 9.24 & 19.19 & 28.25 & 16.72 \\
\hline $\mathrm{CV} \%$ & & & & &
\end{tabular}

Pod number (PN); pod length (PL); pod diameter (PD); fresh pod mass (FMP), and dry pod mass (DPM), irrigated with Water Replacements $(25,50,75,100$, and $125 \%)$. ** Significant at $1 \%$ probability; * Significant at $5 \%$ probability; NS not significant. CV Coefficient of variation.

The arguments apply to the results obtained in analyses for the different WRs in $90 \%$ of the variables when they were significant at $1 \%$ probability, except for pod diameter which revealed highly significant effects. This fact can be justified by the factors plant density and spacing at sowing time, density, and spatial arrangements.

The availability of genotypes adapted to regional edaphoclimatic conditions is important. Factors such as characterization, identification, and selection of genotypes and / or cultivars with potential for cultivation and breeding aim to increase yield and quality of bean (MOREIRA et al., 2009). Determining which cultivar is appropriate to the growing conditions that take into account WR is important. In the present study, it was found that replacement of $125 \%$ was the best for all variables. There was no variation among the cultivars, except for dry mass of pod in which the cultivars showed different behaviour.

The cultivar "Contender" stood out in relation to the variables fresh plant mass, number of pods per plant, and dry and fresh pod mass. The "Amarelo Japonês" cultivar stood out for the variables number of leaves, plant height, and leaf area. The rational and correct management of WR in pod beans cultivation is based on the application of the ideal amount at the right time, thus justifying studies on the WR that performs best as observed in production.

It was observed in the present study that the $100 \%$ and $125 \%$ water replacement rates promoted higher plant performance and bean pod production as shown in the analyses performed in the present research. However, these conditions also offered a microclimate that favored the development of organisms causing physical damage and / or diseases in the plants studied. 

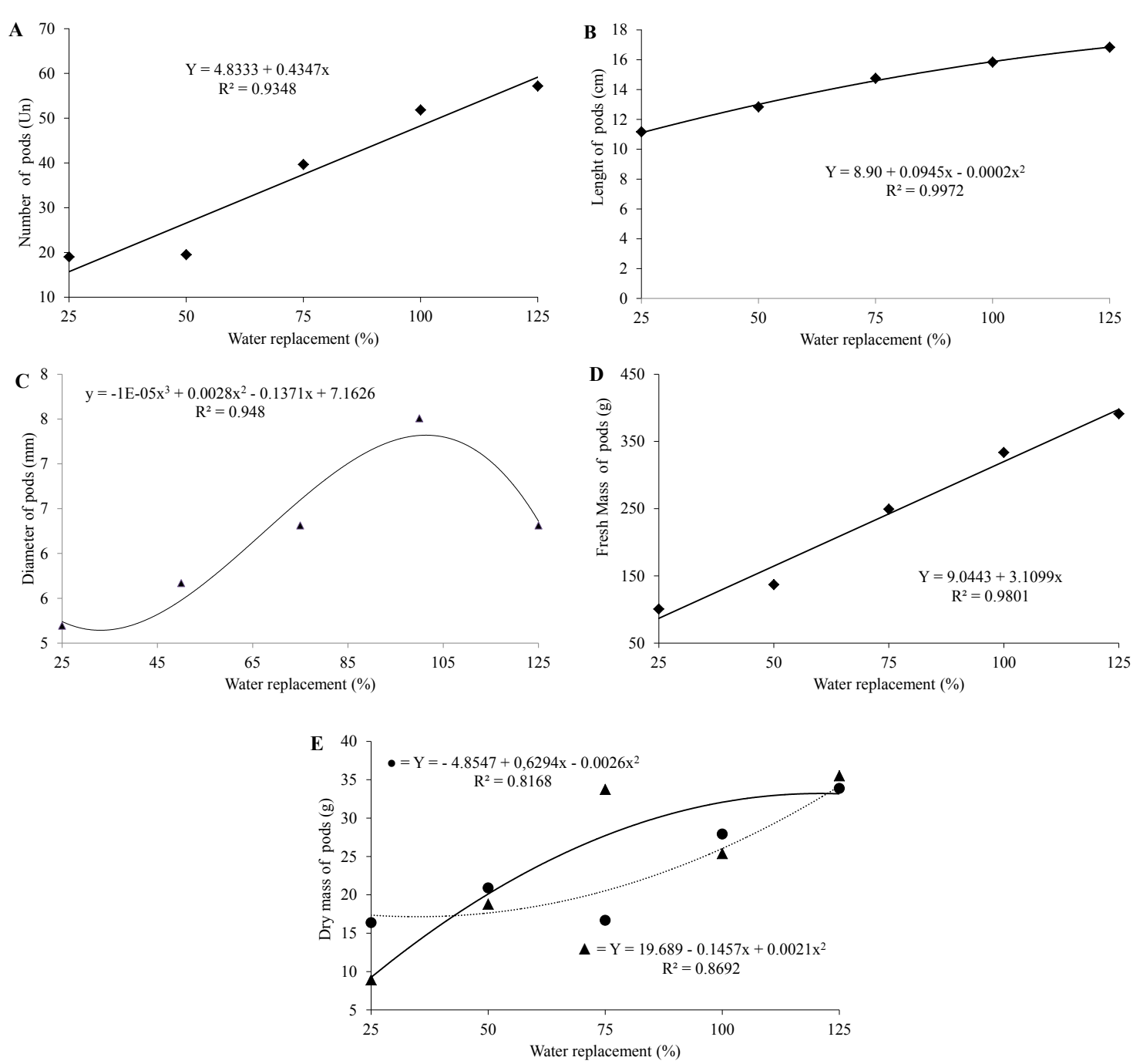

Figure 3. Agronomic and production characteristics of pods ("Amarelo Japonês" and "Contender") for: A) Number of pods; B) Pod length (cm); C) Pod diameter (mm); D) Fresh pod mass (g); E) Pod dry mass (g); irrigated with different water replacements $(25,50,75,100$, and $125 \%)$.

Regarding the yield of legumes and the type of management applied in other species, Halagalimath and Rajkumara (2018) report on the response of chickpea (Cicer arietinum L.) varieties as a function of irrigation and hydrogel application in Vertisol soils, finding that 'JG-11' varieties showed significantly higher pea yields $\left(2.309 \mathrm{~kg} \mathrm{ha}^{-1}\right)$ than other varieties, and that the interaction effect of irrigation levels and varieties was significant for grain yield. This highlights the effects of the environment and genotype on the culture response in each situation.

A study by Moreira et al. (2009) evaluated pod production in different breeding lines and genotypes in different locations, ranging from 7.6 to
$4.1 \mathrm{t} \mathrm{ha}^{-1}$ in Londrina and from 10.1 to $5.0 \mathrm{tha}^{-1}$ in Cambé. The authors also point out that the best overall averages for yield $\left(7.3 \mathrm{t} \mathrm{ha}^{-1}\right)$, number of pods per plant $(6.3)$, and pod length $(14.7 \mathrm{~cm})$ were recorded in Cambé, while the best mean pod diameter $(14.6 \mathrm{~mm})$ was observed in Londrina. These data differ from those in the present study, where it was found that water replacements of $25 \%$ to $125 \%$ contributed to the production of bean pod from 3.00 to $12.00 \mathrm{t} \mathrm{h}^{-1}$ and 3.20 to $12.0 \mathrm{t} \mathrm{h}^{-1}$ for "Amarelo Japonês." This management promoted a rational and correct form of WR in pod bean cultivation, which took into consideration the application of water in the ideal amount, at the right time. 


\section{CONCLUSIONS}

The different water replacement rates promoted increase in the average plant height, stem diameter, number of pods per plant, number of bean seeds per pod, and number of bean seeds per plant in the cultivars "Amarelo Japonês" and "Contender."

Water replacement of $125 \%$ presented superior development than the other replacement levels, regarding the agronomic performance of the two cultivars.

\section{ACKNOWLEDGMENTS}

To the Ministry of Science and Technology (MCT), the National Council for Scientific and Technological Development (CNPq), the Coordination for the Improvement of Higher Education Personnel (Capes), the Goiás Research Support Foundation (FAPEG), the Federal Institute Goiano, Rio Verde Campus and the Goiás State University, Ipameri Campus, for their financial and structural support.

To Professor Jaison Pereira de Oliveira "in memoriam" for his valuable contributions to the development of bean culture.

\section{REFERENCES}

CARVALHO, C. H. M. et al. de. Evolução do crescimento do cafeeiro (Coffea arábica L.) irrigado e não irrigado em duas densidades de plantio. Ciência e Agrotecnologia, v. 30, n. 2, p. 243-250, 2006.

EMPRESA BRASILEIRA DE PESQUISA AGROPECUÁRIA - EMBRAPA. Centro Nacional de Pesquisa de Solos. Sistema Brasileiro de Classificação de Solos. Rio de Janeiro: Embrapa, 2006. 306 p.

FERNANDES, E. J. Determinação do Índice De Estresse Hídrico em Cultura do Feijoeiro com Termômetro de Infravermelho. Irriga, v. 15, n. 3, p. 248-257, 2010.

FERREIRA, D. F. Sisvar: a computerstatistical analysis system. Ciência e Agrotecnologia, v. 35, n. 6, p. 1039-1042, 2011.

FIGUEIREDO, E. S.; SANTOS, M. E.; GARCIA, A. Modelos de Determinação Não Destrutivo da Área Foliar do Feijoeiro Comum (Phaseolus vulgaris L.). Nucleus, v. 9, n. 1, p.79-84, 2012.

FILGUEIRA, F. A. R. Novo manual de olericultura: agrotecnologia moderna na produção e comercialização de hortaliças. 3. ed. Viçosa, MG: UFV, 2013. 421 p.

FILGUEIRA, F. A. R. Novo manual de olericultura: agrotecnologia moderna na produção e comercialização de hortaliças. 2. ed. Viçosa: UFV, 2003. 412 p.

FILGUEIRA, F. A. R. Novo manual de olericultura: agrotecnologia moderna na produção e comercialização de hortaliças. 3. ed. Viçosa: UFV, $2008.421 \mathrm{p}$

HALAGALIMATH, S. P.; RAJKUMARA S.; Response of chicpea (Cicer arietinum L.) varieties to irrigation and hydrogel application in Vertisols. Legume Research: An International Journal, v. 41, n. 2 , p. $259-263,2018$

MANTOVANI, E. C.; BERNARDO, S.; PALARETTI, L. F. Irrigação princípios e métodos. 3.ed. Viçosa: UFV, 2009. 355 p.

MATHEUS, M. T.; LOPES, J. C. Morfologia de frutos, sementes e plântulas e germinação de sementes de Erythrina variegata L. Revista Brasileira de Sementes, v. 29, n. 3, p. 8-17, 2007.

MENDONÇA, F. C.; RASSINI, J. B. Temperaturabase inferior e estacionalidade de produção de gramíneas forrageiras tropicais. São Carlos, SP: Embrapa Pecuária Sudeste, 2006. 14 p. (Circular Técnica, 45).

MOREIRA, R. M. P. et al. Potencial agronômico e divergência genética entre genótipos de feijão-vagem de crescimento determinado Agronomic potential andgenetic divergence among genotypes of bush snap bean. Semina: Ciências Agrárias, v. 30, sup., p. 1051-1060, 2009 .

OLIVEIRA S. R. M. Densidade populacional do feijão-caupi sob níveis de irrigação. 2013. 104 fls. Dissertação (Mestrado em Engenharia Agrícola: Área de Concentração Irrigação e Drenagem) Universidade Federal do Ceará, Fortaleza, 2013.

PEEL, M. C.; FINLAYSON, B. L.; MCMAHON, T. A. Updated World Map of the Köppen-Geiger Climate Classification. Hydrol. Hydrology and Earth System Sciences Discussions, v. 11, n. 5, p. 1633-1644, 2007.

PEIXOTO, C. P. et al. Efeitos de épocas de semeadura e densidade de plantas sobre a produtividade de cultivares de soja no Estado de São Paulo. Revista de Agricultura, v. 77, n. 2, p. 265 291, 2002.

PEIXOTO, N.; CARDOSO, A. I. I.; Feijão-vagem. 
In: NASCIMENTO W. M. N. (ed.). Hortaliças leguminosas. Brasília: EMBRAPA, 2016. p. 61-86.

SILVESTRE, W. V. D. et al. Morphological andphysiological responses of acai seedlings subjected to different watering regimes/Respostas morfológicas e fisiológicas de mudas de açaizeiros submetidas a diferentes regimes hídricos. Revista Brasileira de Engenharia Agrícola e Ambiental, v. 20, n. 4, p. 364-371, 2016.

TAIZ, L. et al. Fisiologia do Desenvolvimento vegetal. 6. Ed. Porto Alegre, RS: Artmed, 2017. 888 p.

ZHANG, J. et al. W. Photosynthetic performance of soy bean plants to water deficit under high and low light intensity. South African Journal of Botany, v. 105, s/n, p. 279-287, 2016. 